\title{
Effect of gene, environment and maternal depressive symptoms on pre-adolescence behavior problems - a longitudinal study
}

\author{
Sara Agnafors ${ }^{1 *}$, Erika Comasco ${ }^{2}$, Marie Bladh³ ${ }^{3}$ Gunilla Sydsjö ${ }^{3}$, Linda DeKeyser ${ }^{3}$, Lars Oreland ${ }^{2}$
} and Carl Göran Svedin ${ }^{1}$

\begin{abstract}
Background: Depression is a common and disabling condition with a high relapse frequency. Maternal mental health problems and experience of traumatic life events are known to increase the risk of behavior problems in children. Recently, genetic factors, in particular gene-by-environment interaction models, have been implicated to explain depressive etiology. However, results are inconclusive.

Methods: Study participants were members of the SESBiC-study. A total of 889 mothers and their children were followed during the child's age of 3 months to 12 years. Information on maternal depressive symptoms was gathered postpartum and at a 12 year follow-up. Mothers reported on child behavior and traumatic life events experienced by the child at age 12. Saliva samples were obtained from children for analysis of 5-HTTLPR and BDNF Val66Met polymorphisms.

Results: Multivariate analysis showed a significant association between maternal symptoms of depression and anxiety, and internalizing problems in 12-year-old children (OR 5.72, 95\% Cl 3.30-9.91). Furthermore, carriers of two short alleles $(\mathrm{s} / \mathrm{s})$ of the 5 -HTTLPR showed a more than 4-fold increased risk of internalizing problems at age 12 compared to I/I carriers (OR 4.73,95\% Cl 2.14-10.48). No gene-by-environment interaction was found and neither depressive symptoms postpartum or traumatic experiences during childhood stayed significant in the final model.

Conclusions: Concurrent maternal symptoms of depression and anxiety are significant risk factors for behavior problems in children, which need to be taken into account in clinical practice. Furthermore, we found a main effect of 5-HTTLPR on internalizing symptoms in 12-year-old children, a finding that needs to be confirmed in future studies.
\end{abstract}

Keywords: Child, Depression, 5-HTTLPR, BDNF, Longitudinal, SESBiC-study

\section{Background}

Depression and anxiety conditions are an increasing problem, leading to substantial economic and social consequences [1]. The prevalence of depression in preadolescents is approximately 1\% [2] and there is an increase in rates of various psychiatric problems during adolescence and adulthood in individuals with a history of childhood depression [3,4]. Moreover, childhood depression has shown a risk factor pattern different from that of adolescent and adult onset depression, raising the

\footnotetext{
* Correspondence: sara.agnafors@liu.se

'Division of Child and Adolescent Psychiatry, IKE, Faculty of Health Sciences, Linköping University, S-581 85 Linköping, Sweden

Full list of author information is available at the end of the article
}

question whether childhood depression is etiologically separate from the latter $[5,6]$.

The longitudinal approach serves as an excellent way of studying risk factors, development and course of psychiatric disorders and symptoms. Many factors may elevate the risk for onset of depression and emotional problems in children. Postpartum depression has been shown to predict child behavior problems in numerous studies $[7,8]$, but there is also support for the fact that on-going maternal depression exerts a risk factor for internalizing as well as externalizing symptoms in children [9-11].

Among other known risk factors for depression and emotional problems are traumatic life events [12] - children exposed to physical abuse, parental divorce and domestic

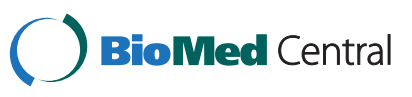


violence are at increased risk of behavior problems and adult depression [13-15]. Still, not everyone subjected to traumatic life events develops depressive symptoms. Hence, there may be individuals predisposed or more vulnerable to certain risk factors.

In recent years, much effort has been given to explaining depression in relation to genetic factors. Many candidate genes have been examined, of which the serotonin transporter gene (5-HTT) is the most studied. The 5-HTT gene includes a functional polymorphism, the serotonin transporter gene-linked polymorphic region (5-HTTLPR), which consists of two common alleles; short (s) and long (l). Less effective serotonin expression and availability have been shown in s-allele carriers, compared to individuals homozygous for the 1 allele [16]. The gene-by-environment model put up by Caspi et al. [17], showing an association between the 5-HTTLPR, stressful life events and depression, has since publication been subjected to numerous attempts at replication. Some researchers have been able to reproduce the results partially or completely [18-24], whereas others have not [25-28], however between-study heterogeneity has to be taken into account. When looking particularly at 5-HTTLPR gene-by-environment studies on children, research is not that extensive and results have been conflicting. Araya et al. [7] found no association between 5-HTTLPR and emotional symptoms in seven-year-olds whereas associations have been shown by other researchers, although on smaller study samples $[20,22,29,30]$. Moreover, also direct association between 5HTTLPR and depression has been found [16,31-34].

Given not only the inconsistency of single genetic explanatory models, but also the complex etiology of depression, researchers have lately been looking at gene-by-gene (-by-environment) models for an explanation of depressive vulnerability. Another candidate gene for depressive disorders is the Brain Derived Neurotrophic Factor (BDNF), which has previously been shown to act in synergy with serotonin [35]. BDNF is involved in reparation, plasticity and neurogenesis in the brain, and a single nucleotide polymorphism (SNP) G/A (Val66Met) in the BDNF gene has been shown to affect levels of $B D N F$ in the brain [36]. Similarly to 5-HTTLPR, studies regarding the association between BDNF Val66Met and depression have been both confirmative [37,38] and negating [39].

A candidate gene-by-gene-by-environment interaction effect of 5-HTTLPR-by-BDNFVal66Met-by-childhood adversity on depression has been shown [40] and to our knowledge four studies have attempted replication of this three-way interaction effect, however with contradictory results [41-44]. The findings are inconsistent regarding both the presence of a three-way interaction effect and the risk genetic variants in the presence of childhood adversity. Two studies found evidence of a three-way interaction effect $[42,44]$ whereas two other studies did not $[41,43]$.
In view of this, the aim of the present paper was to study the gene-by-environment interaction on depressive symptoms in 12-year-old children. We hypothesized to find a gene-by-environment, and possibly gene-by-gene-by-environment interaction on depressive symptoms, including the genetic polymorphisms 5-HTTLPR and BDNF Val66Met, traumatic life events and maternal symptoms of depression.

\section{Methods}

\section{Population and procedures}

This study is part of the South East Sweden Birth Cohort study (SESBiC-study) which started in 1995 with the purpose of early identification of psychosocially burdened families where children were at risk of dysfunctional development. Follow-ups have been carried out at ages 3, 5.5 and 12 and have been reported previously [11,45-48].

\section{Baseline}

All mothers of children from a birth cohort born between May 1st 1995 and December 31st 1996 in southern Sweden were asked to take part in the study, of whom 1723 mothers (88\%) agreed to participate. The mean age of the mothers was $28.2 \pm 4.6$ years at childbirth. Ninety six percent of the mothers $(n=1574)$ were cohabitating, $3.5 \%(\mathrm{n}=57)$ were single parents, while $0.5 \%(\mathrm{n}=8)$ reported other family arrangements. Most mothers were born in Sweden $(88.6 \%),(n=1482)$, but $6.2 \%(\mathrm{n}=103)$ were born in Europe (excluding Sweden), and $5.3 \%(\mathrm{n}=88)$ outside Europe. Of the newborn children, $52.8 \%$ were boys and there were 27 twin pairs. The baseline study was carried out at Child Welfare Centers, (CWC) in connection with the routine 3-month checkup. Questionnaires were administered and a psychologist also interviewed the mothers.

\section{2-year follow-up}

Current home addresses for all 1723 families were obtained from the Swedish Tax Offices. An information letter and a consent form were sent to parents (i.e. legal guardians). Parents who did not return the consent form within three weeks were contacted by phone. A separate, simplified information letter was enclosed for the child. Two children and four mothers were deceased, ten had moved out of the country and 24 were learning disabled and could therefore not participate. These subjects were excluded from the original 1723 in the baseline study, which left 1687 eligible participants, of whom 889 (52.7\%) accepted participation. The follow-up was carried out at school where research assistants met with the children in small groups. The children provided saliva samples and filled out a package of questionnaires separately (as part of a larger study). A package of questionnaires was sent to the mothers' home addresses. Families 
who had moved out of the original catchment area were contacted by mail and phone in accordance with the regular routine. Those who agreed to participate received questionnaires and saliva sampling kits by mail, or if they preferred, were visited by a research assistant and the survey was carried out at the child's home.

\section{Genetic analyses}

The non-invasive and all-in-one Oragene ${ }^{\circledR}$ DNA Collection Kit (DNA Genotek) was used for the collection, stabilization and transportation of saliva samples. DNA was isolated according to the laboratory protocol for manual purification of DNA.

BDNF Val66Met A/G SNP (rs6265) and 5-HTTLPR genotyping were carried out according to previously published protocols [49]. The genotyping was performed blind to psychosocial data. To estimate the quality-rate of genotyping errors, a random repetition of $\sim 13 \%$ of the sample was carried out; the comparison indicated no inconsistencies. The genotypes were in Hardy-Weinberg equilibrium (5-HTTLPR $\left(\chi^{2}=2.73 ; \mathrm{p}=0.10\right)$; females $\left(\chi^{2}=0.44 ; \quad \mathrm{p}=0.51\right) ; \quad$ males $\left(\chi^{2}=2.67 ; \quad \mathrm{p}=0.10\right), \quad B D N F$ Val66Met $\left(\chi^{2}=0.08 ; \mathrm{p}=0.77\right)$; females $\left(\chi^{2}=1.20 ; \mathrm{p}=0.27\right)$; males $\left.\left(\chi^{2}=1.98 ; \mathrm{p}=0.16\right)\right)$.

\section{Questionnaires \\ Baseline}

The Edinburgh Postnatal Depression Scale (EPDS) [50] is a widely used self-report questionnaire designed to screen for post-natal depression. EPDS refers to the 7 days preceding completion of the form and was filled out by the mothers at baseline.

Life Stress Score (LSS) is a 50-item semi-structured interview form, consisting of three main domains regarding the mother's social situation, medical information and psychological circumstances. The LSS has been used previously in a Swedish population based study [51] and was filled out by a psychologist after interviewing the mothers at baseline.

\section{2-year follow-up}

The Child Behavior Check List (CBCL) [52] is a 113item form assessing child behavior, focusing on subscales of internalizing and externalizing behavior respectively. We used the CBCL 4-18 years, which was filled out by the mothers at the child's age of 12 .

The Hopkins Symptom Checklist (HSCL-25), a short version of the HSCL-90 [53] was used to measure symptoms of anxiety and depression during the most recent 14 days. The HSCL-25 was filled out by the mothers at the 12-year follow-up.

To assess potentially traumatic life events experienced by the child, the Swedish version of Life Incidence of Traumatic Events (LITE) was used [54,55]. The 16-item parent report form (LITE-P) was filled out by the mothers at the child's age of 12 .

\section{Data analysis}

In accordance with previous studies, we used two cut offs for the EPDS in order to catch depressive symptoms of different severity. The first (cut off 10) representing a screening level [50] and the second (cut off 13) supposed to catch more severe clinical depressive symptomatology [56]. For the HSCL-25 total score, a mean item score of 1.75 was used as cut off, as has been used previously [57]. On the CBCL and LSS scales, the 90th percentile was set as a cut off. Results on the LITE form were dichotomized into 0-2 events and $\geq 3$ events, for which there is support in the literature [17]. Bivariate analyses between genetic markers (5-HTTLPR and BDNF Val66Met) and psychological scales (CBCL), as well as between scales (EPDS, HSCL-25, $\mathrm{CBCL}$ ), were performed using the chi-square statistic. Multivariate analyses, with CBCL scales as dependent variables and psychological scales, socio-demographic variables (LSS) and genetic markers as independent variables were also performed. Ethnic background (both parents born in Sweden, compared to one or both parents born abroad) and sex of the child were also controlled for. The multivariate analysis consisted of conditional stepwise logistic regression considering full factorial models. However, since this procedure may choose models containing interactions without corresponding main effects, the models have been corrected for this and further evaluated and reduced to include models with significant main effects and appropriate corresponding interactions. Results are presented with corresponding Odds Ratios (OR) and 95\% Confidence Intervals $(\mathrm{CI})$. All statistical analyses were performed using IBM SPSS version 19 (IBM Corporation, Armonk, NY).

\section{Dropout rate analysis}

At the 12-year follow-up, the total dropout rate was $47.3 \%$ $(n=798)$. There was a difference when comparing immigrant status between participants and non-participants at the 12 year follow-up, where $54.6 \%(n=802)$ of mothers born in Sweden $(n=1468)$ took part compared to $44.6 \%$ $(n=45)$ of mothers born in Europe $(n=101)$ and $34.9 \%$ $(n=30)$ of mothers born outside of Europe $(n=86)$ $\left(x^{2}=15.79, p=0.00\right)$. Likewise, differences were found between participants and non-participants at the follow-up when comparison for socio-demographic factors at baseline was made. Of mothers who scored above cut-off on the LSS total scale at baseline $(n=141), 60.3 \%(n=85)$ took part in the follow-up compared to $70.7 \%(n=1093)$ of mothers with low total score at baseline $(n=1546)$ $(x 2=6.65, p=0.01)$. No differences were found between participants and non-participants at the 12-year follow-up regarding symptoms of postpartum depression. 
Table 1 Odds ratios in predicting CBCL subscales at age 12

\section{Internalizing symptoms $\geq$ 90th percentile}

Odds ratio

$95.0 \% \mathrm{Cl}$ for odds ratio

p-value

BDNF Val/Met compared to Val/Nal

BDNF Met/Met compared to Val/Nal

1.37

0.82

5HTTLPR s/l compared to I/I

1.78

5HTTLPR s/s compared to $\mathrm{I} / \mathrm{I}$

4.43

LITE

1.70

EPDS screening cut off 10

1.90

Clinical cut off 13

3.09

HSCL-25

LSS

Sex

Ethnicity

Anxious depressed $\geq$ 90th percentile

BDNF Val/Met compared to Val/Nal

BDNF Met/Met compared to Val/Nal

5HTTLPR s/l compared to I/I

5HTTLPR s/s compared to I/I

LITE

EPDS screening cut off 10

Clinical cut off 13

HSCL-25

LSS

Sex

Ethnicity

5.92

4.03

0.63

1.93

0.99

0.64

1.10

2.32

1.72

1.84

2.72

4.76

3.53

0.59

1.19

Withdrawn depressed $\geq$ 90th percentile

BDNF Val/Met compared to Val/Nal

BDNF Met/Met compared to Val/Val

5HTTLPR s/I compared to $\mathrm{l} / \mathrm{I}$

5HTTLPR s/s compared to I/I

LITE

EPDS screening cut off 10

Clinical cut off 13

2.04

2.68

HSCL-25

LSS

Sex

Ethnicity

4.54

1.52

1.28

2.22

Externalizing symptoms $\geq$ 90th percentile

BDNF Val/Met compared to Val/Nal

BDNF Met/Met compared to Val/Nal

5-HTTLPR s/l compared to I/I

5-HTTLPR s/s compared to I/I

LITE

EPDS screening cut off 10

Clinical cut off 13
$0.82-2.29$

$0.19-3.52$

0.84-3.76

2.09-9.38

1.04-2.80

0.98-3.68

1.30-7.34

3.59-9.77

$1.95-8.35$

$0.38-1.04$

$1.02-3.67$

0.59-1.64

0.15-2.76

$0.59-2.06$

$1.22-4.42$

$1.07-2.72$

$0.97-3.49$

$1.15-6.43$

$2.95-7.70$

$1.71-7.28$

$0.37-0.96$

0.59-2-39

0.95-2.51

$0.17-3.26$

$0.68-2.38$

1.29-4.77

0.83-2.10

1.09-3.81

1.13-6.34

2.82-7.30

0.62-3.69

0.81-2.03

$1.22-4.01$

0.78-2.10

0.51-4.46

0.86-3.01

1.23-4.75

$1.02-2.56$

1.13-3.80

$1.07-5.97$
0.33

0.47

0.14

0.01

0.04

0.24

0.78

0.13

$<0.01$

0.04

0.06

0.01

$<0.001$

$<0.001$

0.07

0.04

0.96

0.55

0.76

0.01

0.03

0.06

0.02

$<0.001$

0.001

0.03

0.63

0.80

0.70

0.46

0.07

0.24

0.03

0.02

$<0.001$

0.36

0.30

0.01

0.02

0.03 
Table 1 Odds ratios in predicting CBCL subscales at age 12 (Continued)

\begin{tabular}{llll}
\hline HSCL-25 & 5.20 & $3.26-8.28$ & $<0.001$ \\
LSS & 2.07 & $0.93-4.62$ & 0.08 \\
Sex & 1.86 & $1.17-2.95$ & 0.01 \\
Ethnicity & 1.89 & $1.04-3.46$ & 0.04 \\
\hline
\end{tabular}

Note: $\mathrm{Cl}=$ Confidence Interval, $\mathrm{CBCL}=$ Child Behavior Checklist, BDNF = Brain Derived Neurotrophic Factor, 5-HTTLPR = serotonin transporter gene-linked polymorphic region, LITE = Life Incidence of Traumatic Events, EPDS = Edinburgh Postnatal Depression Scale, HSCL-25 = Hopkins Symptom Checklist 25, LSS = Life Stress Score.

Logistic regression. Dependent variables: $\mathrm{CBCL}$ (internalizing symptoms, internalizing symptoms divided into 1) anxious depressed and 2) withdrawn depressed, and externalizing symptoms). Independent variables ( 0 is used as a reference level): LITE $(0 \leq 2,1 \geq 3)$, EPDS $(0 \leq 9,1 \geq 10)$ and $(0 \leq 12,1 \geq 13), H S C L-25(0=m e a n$ score $<1.75$, $1=$ mean score $\geq 1.75$ ): LSS ( $0<90$ th percentile, $1 \geq 90$ th percentile) sex $(0=$ girls and $1=$ boys $)$ and ethnicity $(0=S w e d i s h ~ 1=2$ nd generation immigrants).

\section{Ethical approval}

The study outline was approved by the Ethics committee at the University of Lund in 1994 and 1998 and by The Regional Ethical Review Board in Linköping 2007.

\section{Results}

The frequencies of 5-HTTLPR genotypes were 1/1 31\%, s/l 47\% and s/s 22\%. The frequencies of BDNF Val66Met genotypes were $\mathrm{Val} / \mathrm{Val} 65 \%$, $\mathrm{Val} / \mathrm{Met} 31 \%$, Met/Met $4 \%$.

\section{Bivariate analysis}

In bivariate analysis, maternal symptoms of depression and anxiety at the 12-year follow up increased the risk for internalizing problems in the children more than fivefold (OR 5.92, CI 3.59-9.77). There was an increase of risk also for the subscales anxious depressed and withdrawn depressed (OR 4.76, CI 2.95-7.70; OR 4.54, CI 2.82-7.30). A fivefold risk increase was seen for externalizing problems (OR 5.20, CI 3.26-8.28) (Table 1).

Using the screening cut off of 10 on EPDS no effect was seen for maternal depressive symptoms postpartum on internalizing problems and the subscale anxious depressed in the children. There was an increase of risk for withdrawn depressive symptoms (OR 2.04, CI 1.09-3.81) and externalizing symptoms (OR 2.07, CI 1.13-3.80) if the mother reported on depressive symptoms postpartum (Table 1). Using the higher cut off of 13 reduced the number of EPDS positive mothers from 92 to 35 . The association between maternal depressive symptoms postpartum and all CBCL scales were strengthened using the clinical cut off of 13 on the EPDS (Table 1).

Analysis further showed that 5-HTTLPR s/s carriers had more internalizing problems at age 12 compared to l/l carriers (OR 4.43, CI 2.09-9.38). The same applied for the subscales anxious depressed and withdrawn depressed (OR 2.32, CI 1.22-4.42; OR 2.48, CI 1.29-4.77) as well as for externalizing problems (OR 2.4, CI 1.23-4.75). Differences between $\mathrm{s} / \mathrm{l}$ and $\mathrm{l} / \mathrm{l}$ carriers were not significant. No effect was seen for BDNF Val66Met genotype on child behavior problems (Table 1).
Traumatic life events increased the risk for internalizing and externalizing problems in the children (OR 1.70, CI 1.04-2.80; OR 1.62, CI 1.02-2.56). For the subscale anxious depressed, there was an increase of risk (OR 1.72, CI 1.072.72 ), but not concerning the subscale withdrawn depressed (Table 1).

Maternal life stress at baseline increased the risk for internalizing problems in the children (OR 4.03, CI 1.958.35). A risk increase was also seen for the subscale anxious depressed (OR 3.53, CI 1.71-7.28), but not for withdrawn depressed and externalizing problems (Table 1).

Children with a non-Swedish background had an increased risk for both internalizing and externalizing problems (OR 1.93, CI 1.02-3.67; OR 1.89, CI 1.04-3.46) compared to children with a Swedish background. They also indicated an increased risk on the subscale withdrawn depressed (OR 2.22, CI 1.22-4.01) (Table 1). Boys had an increased risk for externalizing problems compared to girls (OR 1.86, CI 1.17-2.95), whereas girls had an increased risk on the subscale anxious depressed (OR 0.59, CI 0.37-0.96) (Table 1).

\section{Multivariate analysis}

In the stepwise multivariate analysis using cut off of 10 on EPDS, maternal symptoms of depression and anxiety at the child's age of 12 increased the risk for both internalizing and externalizing behavior problems in the children (OR 5.72, CI 3.30-9.91; OR 5.47, CI 3.40-8.78). When dividing the internalizing scale into the subscales anxious depressed and withdrawn depressed, the effect remained only for the latter (OR 4.27, CI 2.57-7.10) (Figure 1).

5-HTTLPR s/s carriers had a more than 4-fold increased risk of internalizing problems at age 12 compared to $1 / 1$ carriers (OR 4.73, CI 2.14-10.48). Likewise, a risk increase was seen for the subscales anxious depressed and withdrawn depressed (OR 2.41, CI 1.25-4.62; OR 2.30, CI 1.184.51) (Figure 1). Differences between $\mathrm{s} / \mathrm{l}$ and $\mathrm{l} / \mathrm{l}$ carriers were not significant. The BDNF Val66Met polymorphism did not show an impact on child behavior, and was not included in the final models.

Maternal life stress at baseline increased the risk for internalizing problems in 12-year old children (OR 3.42, 
CI 1.43-8.21). This was true also for the subscale anxious depressed (OR 3.91, CI 1.81-8.44) (Figure 1). No effect was seen for LITE on any of the models.

Boys had an increased risk of externalizing problems compared to girls (OR 1.84, CI 1.14-2.97). No other differences relating to sex were detected.

The only change when using a cut off of 13 on EPDS was seen concerning the outcome in the model for the subscale anxious depressed. The significance of 5HTTLPR disappeared while both being girl (OR 0.53, CI $0.32-0.87$ ) and maternal symptoms of depression and anxiety at the child's age of 12 (OR 4.62 CI 2.81-7.58) increased the risk for being anxious depressed according to the CBCL subscale. No separate significant effect was seen for EPDS using either of the two cut offs.

There was no evidence for gene-by-environment interactions, or gene-by-gene-by-environment interactions. Furthermore, we tested whether there was an interaction between ethnic background and 5-HTTLPR and BDNF Val66Met polymorphisms respectively on the outcome of child behavior problems, but no such interaction was found (for all factors and interactions tested, see Additional file 1).

\section{Discussion}

This study used data from a longitudinal birth cohort study in order to examine predictors of internalizing and externalizing symptoms in 12-year old children. Environmental as well as genetic factors were included in order to test for gene-by-environment and gene-by-gene-byenvironment interactions. The results of the study can be summarized in three main findings.

First and foremost, maternal symptoms of depression and anxiety predicted child behavior problems at age 12 . Numerous researchers have been able to show the importance of maternal mental health for child development and wellbeing. Our results indicate that in the present population, maternal symptoms of postpartum depression (analyzed with different cut off scores on the EPDS) did not have a long-term impact on child behavior, i.e., no increase of risk was seen at age 12. Symptoms of depression in mothers at the 12-year follow-up could possibly reflect recurrent or chronic depressive problems, which would put the child under greater stress than would be the case with a single episode depression. In clinical practice, we suggest that besides focusing on the child's mental health, it is important also to ask about depressive symptoms in the mother.

Second, we found a main gene effect of 5-HTTLPR on child behavior at age 12. Since the finding of an interaction between 5-HTTLPR and stressful life events [17], focus of research has shifted to gene-by-environment interaction effects. The present finding does have support in the literature [16,31-34], however most gene-by -environment studies have not shown a main effect of 5-
HTTLPR on depression [20,21]. Recently, Duncan and Keller reviewed the literature on candidate gene-by-environment interaction (cGxE) studies in psychiatry over a decade (2000-2009), and based on the analyses of 103 studies suggested that "well-powered direct replications deserve more attention than novel $\mathrm{CG} \times \mathrm{E}$ findings and indirect replications" [58]. The current study attempted testing a previous hypothesis and replicating previous findings in a large and longitudinal population-based independent study/sample. The set-up of the current study can help to understand the generalizability of previous findings since it used a virtually similar set-up compared to previous studies with regard to phenotypic variables, genetic polymorphisms, statistical model, environmental moderator, and inclusion of both sexes [58]. This represents a major strength of the current study which might contribute to the drawing of clearer conclusions in the context of future meta-analytical studies. The present study did not find any GxE or GxGxE effects but rather a main effect of 5-HTTLPR on internalizing symptoms as for example showed by Hoefgren et al. in a case-control study on depression [31].

Third, traumatic life events showed an impact on child behavior in bivariate models, but not in the multivariate analyses, indicating that in this material, life events did not explain as much of the variance as other factors. We used the mothers' reports on traumatic life events experienced by the children. Previous studies have shown differences between parents' reports and children's self-reports on exposure to violence [59]. Considering this, self-reports might have contributed to a more fair estimation of traumatic life events experienced by the child. Given the known relationship between life events and depressive symptoms, one would have expected an effect on the internalizing scales $[12,15,17]$.

We included measure of externalizing problems since previous research has shown high comorbidity between depressive and externalizing disorders in adolescents [60] and since boys more often express their psychological problems or stress by showing externalizing problems [2]. Furthermore, Laucht et al. [61] reported that adolescents with depressive disorders were more likely to have a history of externalizing problems. As expected, the analysis showed that boys expressed significantly more externalizing problems than girls, but there were no differences relating to sex for internalizing problems.

Despite the dropout level, the number of its participants and the longitudinal approach strengthens the study. There are some limitations that need to be mentioned. Although dropout rates of the same magnitude in longitudinal, multi wave studies are common [7], the skewed dropout in this study is a limitation - psychosocially disadvantaged families and families of foreign origin were less likely to participate in the follow-up. Considering the known connection 


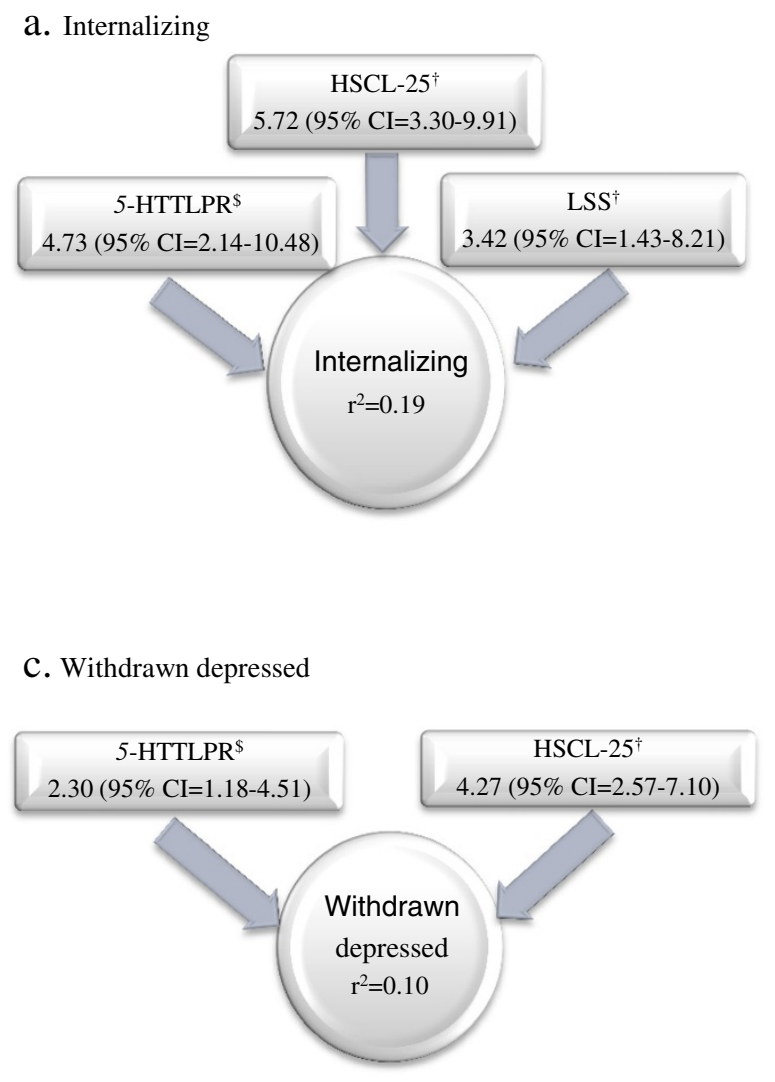

b. Anxious depressed

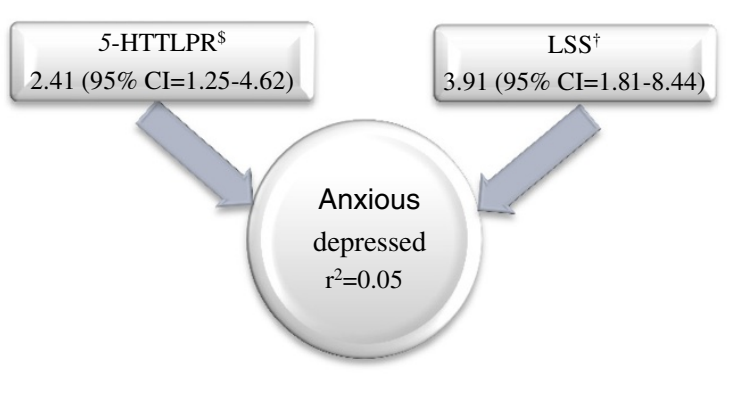

d. Externalizing

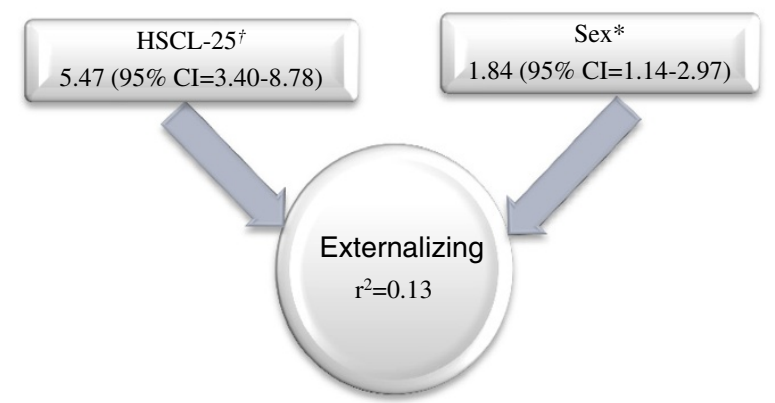

Figure 1 Odds ratios for the studied CBCL outcomes and corresponding measure of $\mathbf{r}$. \$Comparing $\mathrm{s} / \mathrm{s}$ with $\mathrm{I} / \mathrm{I}$ as reference. $+\mathrm{Comparing}$ risk with no risk as reference. ${ }^{*}$ Comparing boys with girls as reference. Note: $\mathrm{CBCL}=$ Child Behavior Checklist, ${ }^{2}{ }^{2}$ the amount of variance explained by the model, 5-HTTLPR = serotonin transporter gene-linked polymorphic region, HSCL-25 = Hopkins Symptom Checklist 25, LSS = Life Stress Score. Multivariate analysis. CBCL scales presented are a) internalizing symptoms, internalizing subscales $\mathbf{b}$ ) anxious depressed and $\mathbf{c}$ ) withdrawn depressed, and $\mathbf{d}$ ) externalizing symptoms.

between psychosocial strain and behavior problems, it is plausible to think that a more representative participating population would have strengthened the results.

In general, both child and parent-reports indicated low frequencies of behavior problems. Reports on good mental health in 12-year old children have been published previously. Costello et al. [2] examined mental health in 9-16 year old children using parent's reports on child behavior (CBCL) and clinical interviews, and found the lowest prevalence of depression in 12-year olds (0.4\%). Conducting the follow-up at ages eight-ten or during adolescence, where previous reports have shown more behavior problems, might have increased the prevalence rate and thereby rendering a larger group for different analyses.

Since there are studies indicating that depressed mothers are prone to overestimate behavior problems in their children [62], another limitation of the present study is that mothers' reports, not self-reports or teachers' reports, on child behavior and traumatic life events were used. We decided to use mothers as informants since they have known their children for 12 years around the clock compared to the current teachers that have known the children for about just over a year 5-6 hours a day, five days a week. Another support for this strategy was that although the association between maternal depressive symptoms and a positive mother-child reporting discrepancy has been demonstrated, in the general population this association is small and does not bias research, using maternal reports on child problems [62]. The chosen methodology used in the study also allowed following data from the same informants from baseline to the 12-year follow-up.

Feder, Nestler and Charney's report of 2009 called for an increased understanding of the psycho-biological factors which are involved in risk and resiliency for psychiatric disorders [63], and Duncan and Keller's review called for well-powered direct replications of $\mathrm{cG} \times \mathrm{E}$ findings [58]. Thus, many studies are still to be carried out to shed light on the psychogenetic underpinning of depression. 


\section{Conclusion}

In conclusion the present study suggests that concurrent maternal symptoms of depression and anxiety are an important risk for behavior problems in children, which needs to be taken into account in clinical practice. Furthermore, we found a main effect of 5-HTTLPR on internalizing symptoms in 12 year old children, a finding that need to be confirmed in future studies.

\section{Additional file}

Additional file 1: Factors and interactions included in multivariate analysis. The additional file holds a list of all factors and interactions between factors tested in multivariate analysis.

\section{Competing interests}

The authors declare that they have no competing interests.

\section{Authors' contributions}

SA was responsible for the data collection, and for writing the manuscript EC was responsible for the genetic analyses, and made substantial contribution to the writing of the manuscript. MB was responsible for the statistical analyses, and took part in writing the manuscript. LD took part in data collection and writing the manuscript. CGS and GS planned and supervised the research project. LO took part in planning the project and supervised the genetic analyses. All authors took part in reviewing draft versions of the manuscript, and approved of the final version.

\section{Acknowledgements}

We thank the Swedish Council for Working Life and Social Research (FAS), the Swedish Research Council (VR), Clas Groschinsky memorial foundation, Hållsten research foundation and ALF, County council of Östergötland, for financial support, Professor emerita Marianne Cederblad for her work with the earlier waves of the study and Dr Niklas Nordquist for the skillful technical assistance.

\section{Author details}

${ }^{1}$ Division of Child and Adolescent Psychiatry, IKE, Faculty of Health Sciences, Linköping University, S-581 85 Linköping, Sweden. ${ }^{2}$ Division of Pharmacology, Department of Neuroscience, Uppsala University, BMC, Box 593, S-751 24 Uppsala, Sweden. ${ }^{3}$ Division of Obstetrics and Gynecology IKE, Faculty of Health Sciences, Linköping University, S-581 85 Linköping, Sweden.

Received: 7 October 2012 Accepted: 11 March 2013

Published: 22 March 2013

\section{References}

1. Johnston K, Westerfield W, Momin S, Philippi R, Naldoo A: The direct and indirect costs of employee depression, anxiety, and emotional disorders an employer case study. J Occup Environ Med 2009, 51:564-577.

2. Costello EJ, Mustillo S, Erkanli A, Keeler G, Angold A: Prevalence and development of psychiatric disorders in childhood and adolescence. Arch Gen Psychiatry 2003, 60(8):837-844.

3. Kim-Cohen J, Caspi A, Moffitt TE, Harrington H, Milne BJ, Poulton R: Prior juvenile diagnoses in adults with mental disorder: developmental follow-back of a prospective-longitudinal cohort. Arch Gen Psychiatry 2003, 60(7):709-717.

4. Copeland WE, Shanahan L, Costello EJ, Angold A: Childhood and adolescent psychiatric disorders as predictors of young adult disorders. Arch Gen Psychiatry 2009, 66(7):764-772

5. Jaffee SR, Moffitt TE, Caspi A, Fombonne E, Poulton R, Martin J: Differences in early childhood risk factors for juvenile-onset and adult-onset depression. Arch Gen Psychiatry 2002, 59(3):215-222.

6. Hill J, Pickles A, Rollinson L, Davies R, Byatt M: Juvenile- versus adult-onse depression: multiple differences imply different pathways. Psychol Med 2004, 34(8):1483-1493.
7. Araya R, Hu X, Heron J, Enoch MA, Evans J, Lewis G, Nutt D, Goldman D: Effects of stressful life events, maternal depression and 5-HTTLPR genotype on emotional symptoms in pre-adolescent children. Am J Med Genet B Neuropsychiatr Genet 2009, 150B(5):670-682.

8. Fihrer I, McMahon CA, Taylor AJ: The impact of postnatal and concurrent maternal depression on child behavior during the early school years. J Affect Disord 2009, 119:116-123.

9. Hammen C, Brennan PA, Shih JH: Family discord and stress predictors of depression and other disorders in adolescent children of depressed and nondepressed women. J Am Acad Child Adolesc Psychiatry 2004, 43(8):994-1002.

10. Luoma I, Tamminen T, Kaukonen P, Laippala P, Puura K, Salmelin R, Almqvist F: Longitudinal study of maternal depressive symptoms and child well-being. J Am Acad Child Adolesc Psychiatry 2001, 40(12):1367-1374.

11. Agnafors S, Sydsjö G, DeKeyser L, Svedin CG: Symptoms of Depression Postpartum and 12 years Later-Associations to Child Mental Health at 12 years of Age. Matern Child Health J 2012 [Epub ahead of print]

12. Tennant C: Life events, stress and depression: a review of recent findings. Aust N Z J Psychiatry 2002, 36(2):173-182.

13. Rønning JA, Haavisto A, Nikolakaros G, Helenius H, Tamminen T, Moilanen I, Kumpulainen K, Piha J, Almqvist F, Sourander A: Factors associated with reported childhood depressive symptoms at age 8 and later self-reported depressive symptoms among boys at age 18. Soc Psychiatry Psychiatr Epidemiol 2011, 46(3):207-218.

14. Chapman DP, Whitfield CL, Felitti VJ, Dube SR, Edwards VJ, Anda RF: Adverse childhood experiences and the risk of depressive disorders in adulthood. J Affect Disord 2004, 82(2):217-225.

15. Carter AS, Wagmiller RJ, Gray SA, McCarthy KJ, Horwitz SM, Briggs-Gowan MJ: Prevalence of DSM-IV disorder in a representative, healthy birth cohort at school entry: sociodemographic risks and social adaptation. J Am Acad Child Adolesc Psychiatry 2010, 49(7):686-698.

16. Lesch KP, Bengel D, Heils A, Sabol SZ, Greenberg BD, Petri S, Benjamin J, Muller CR, Hamer DH, Murphy DL: Association of anxiety-related traits with a polymorphism in the serotonin transporter gene regulatory region. Science 1996, 274:1527-1531.

17. Caspi A, Sugden K, Moffit TE, Taylor A, Craig IW, Harrington H: Influence of life stress on depression: Moderation by a polymorphism in the $5-\mathrm{HTT}$ gene. Science 2003, 301:386-389.

18. Wilhelm K, Mitchell PB, Niven H, Finch A, Wedgwood L, Scimone A, Blair IP, Parker G, Schofield PR: Life events, first depression onset and the serotonin transporter gene. Br J Psychiatry 2006, 188:210-215.

19. Cervilla JA, Molina E, Rivera M, Torres-González F, Bellón JA, Moreno B, Luna JD, Lorente JA, Mayoral F, King M, Nazaret I, PREDICT Study Core Group, Gutiérrez B: The risk for depression conferred by stressful life events is modified by variation at the serotonin transporter 5 HTTLPR genotype: evidence from the Spanish PREDICT-Gene cohort. Mol Psychiatry 2007, 12(8):748-755.

20. Kaufman J, Yang BZ, Douglas-Palumberi H, Houshyar S, Lipschitz D, Krystal $\mathrm{JH}$, Gelernter J: Social supports and serotonin transporter gene moderate depression in maltreated children. Proc Natl Acad Sci USA 2004, 101(49):17316-17321

21. Kendler KS, Kuhn JW, Vittum J, Prescott CA, Riley B: The interaction of stressful life events and a serotonin transporter polymorphism in the prediction of episodes of major depression: a replication. Arch Gen Psychiatry 2005, 62(5):529-535.

22. Eley TC, Sugden K, Corsico A, Gregory AM, Sham P, McGuffin P, Plomin R, Craig IW: Gene-environment interaction analysis of serotonin system markers with adolescent depression. Mol Psychiatry 2004, 9(10):908-915.

23. Grabe HJ, Lange M, Wolff B, Völzke H, Lucht M, Freyberger HJ, John U, Cascorbi I: Mental and physical distress is modulated by a polymorphism in the 5-HT transporter gene interacting with social stressors and chronic disease burden. Mol Psychiatry 2005, 10(2):220-224.

24. Taylor SE, Way BM, Welch WT, Hilmert CJ, Lehman BJ, Eisenberger NI: Early family environment, current adversity, the serotonin transporter promoter polymorphism, and depressive symptomatology. Biol Psychiatry 2006, 60(7):671-676.

25. Gillespie NA, Whitfield JB, Williams B, Heath AC, Martin NG: The relationship between stressful life events, the serotonin transporter (5-HTTLPR) genotype and major depression. Psychol Med 2005, 35(1):101-111.

26. Surtees PG, Wainwright NW, Willis-Owen SA, Luben R, Day NE, Flint J: Social adversity, the serotonin transporter (5-HTTLPR) polymorphism and major depressive disorder. Biol Psychiatry 2006, 59(3):224-229. 
27. Chipman P, Jorm AF, Prior M, Sanson A, Smart D, Tan X, Easteal S: No interaction between the serotonin transporter polymorphism (5-HTTLPR) and childhood adversity or recent stressful life events on symptoms of depression: results from two community surveys. Am J Med Genet $B$ Neuropsychiatr Genet 2007, 144B(4):561-565.

28. Chorbov VM, Lobos EA, Todorov AA, Heath AC, Botteron KN, Todd RD: Relationship of 5-HTTLPR genotypes and depression risk in the presence of trauma in a female twin sample. Am J Med Genet B Neuropsychiatr Genet 2007, 144B(6):830-833.

29. Hankin BL, Jenness J, Abela JR, Smolen A: Interaction of 5-HTTLPR and idiographic stressors predicts prospective depressive symptoms specifically among youth in a multiwave design. J Clin Child Adolesc Psychol 2011, 40(4):572-585.

30. Nobile M, Rusconi M, Bellina M, Marino C, Giorda R, Carlet O, Vanzin L, Molteni M, Battaglia M: The influence of family structure, the TPH2 G-703 T and the 5-HTTLPR serotonergic genes upon affective problems in children aged 10-14 years. J Child Psychol Psychiatry 2009, 50(3):317-325.

31. Hoefgen B, Schulze TG, Ohlraun S, von Widdern O, Höfels S, Gross M, Heidmann V, Kovalenko S, Eckermann A, Kölsch H, Metten M, Zobel A, Becker T, Nöthen MM: The power of sample size and homogenous sampling: association between the 5-HTTLPR serotonin transporter polymorphism and major depressive disorder. Biol Psychiatry 2005, 57(3):247-251.

32. Clarke H, Flint J, Attwood AS, Munafò MR: Association of the 5- HTTLPR genotype and unipolar depression: a meta-analysis. Psychol Med 2010, 40(11):1767-1778.

33. Cervilla JA, Rivera M, Molina E, Torres-González F, Bellón JA, Moreno B, de Dios LJ, Lorente JA, de Diego-Otero Y, King M, Nazareth I, Gutiérrez B, PREDICT Study Core Group: The 5-HTTLPR s/s genotype at the serotonin transporter gene (SLC6A4) increases the risk for depression in a large cohort of primary care attendees: the PREDICT-gene study. Am J Med Genet B Neuropsychiatr Genet 2006, 141B(8):912-917.

34. Kiyohara C, Yoshimasu K: Association between major depressive disorder and a functional polymorphism of the 5-hydroxytryptamine (serotonin) transporter gene: a meta-analysis. Psychiatr Genet 2010, 20(2):49-58.

35. Martinowich K, Lu B: Interaction between BDNF and serotonin: role in mood disorders. Neuropsychopharmacology 2008, 33(1):73-83.

36. Egan MF, Kojima M, Callicott JH, Goldberg TE, Kolachana BS, Bertolino A, Zaitsev E, Gold B, Goldman D, Dean M, Lu B, Weinberger DR: The BDNF val66met polymorphism affects activity-dependent secretion of BDNF and human memory and hippocampal function. Cell 2003, 112(2):257-269.

37. Hwang JP, Tsai SJ, Hong CJ, Yang CH, Lirng JF, Yang YM: The Val66Met polymorphism of the brain-derived neurotrophic-factor gene is associated with geriatric depression. Neurobiol Aging 2006, 27(12):1834-1837.

38. Strauss J, Barr CL, George CJ, Devlin B, Vetró A, Kiss E, Baji I, King N, Shaikh S, Lanktree M, Kovacs M, Kennedy JL: Brain-derived neurotrophic factor variants are associated with childhood-onset mood disorder: confirmation in a Hungarian sample. Mol Psychiatry 2005, 10(9):861-867.

39. Surtees PG, Wainwright NW, Willis-Owen SA, Sandhu MS, Luben R, Day NE, Flint J: No association between the BDNF Val66Met polymorphism and mood status in a non-clinical community sample of 7389 older adults. J Psychiatr Res 2007, 41(5):404-409.

40. Kaufman J, Yang BZ, Douglas-Palumberi H, Grasso D, Lipschitz D, Houshyar S, Krystal JH, Gelernter J: Brain-derived neurotrophic factor-5-HTTLPR gene interactions and environmental modifiers of depression in children. Biol Psychiatry 2006, 59(8):673-680.

41. Aguilera M, Arias B, Wichers M, Barrantes-Vidal N, Moya J, Villa H, van Os J, Ibanez MI, Ruiperez MA, Ortet G, Fananas L: Early adversity and 5-HTT/BDNF genes: new evidence of gene-environment interactions on depressive symptoms in a general population. Psychol Med 2009, 39(9):1425-1432.

42. Grabe HJ, Schwahn C, Mahler J, Appel K, Schulz A, Spitzer C, Fenske K, Barnow S, Freyberger HJ, Teumer A, Petersmann A, Biffar R, Rosskopf D, John U, Volzke H: Genetic epistasis between the brain-derived neurotrophic factor Val66Met polymorphism and the 5-HTT promoter polymorphism moderates the susceptibility to depressive disorders after childhood abuse. Prog Neuropsychopharmacol Biol Psychiatry 2012, 36(2):264-270

43. Nederhof E, Bouma EM, Oldehinkel AJ, Ormel J: Interaction between childhood adversity, brain-derived neurotrophic factor $\mathrm{val} / \mathrm{met}$ and serotonin transporter promoter polymorphism on depression: the TRAILS study. Biol Psychiatry 2010, 68(2):209-212.
44. Wichers M, Kenis $G$, Jacobs N, Mengelers R, Derom C, Vlietinck R, van Os J: The BDNF Val(66)Met $\times 5$-HTTLPR $x$ child adversity interaction and depressive symptoms: $A n$ attempt at replication. Am J Med Genet $B$ Neuropsychiatr Genet 2008, 147B(1):120-123.

45. Cederblad M, Höök B, Berg R: [Screening of psychosocial risk factors during infancy and childhood]. Socialmedicinsk tidskrift 2005, 82:158-170. In Swedish.

46. Cederblad M, Höök B: [Psychosocial health among second-generation immigrant children in preschool age: risk- and resilient factors] Psykosocial hälsa hos andra generationens invandrarbarn under förskoleåren: risk- och friskfaktorer. Socialmedicinsk tidskrift 2006 83:217-229. In Swedish.

47. Höök B, Cederblad M, Berg R: Prenatal and postnatal maternal smoking as risk factors for preschool children's mental health. Acta Paediatr 2006, 95:671-677.

48. Dekeyser L, Svedin CG, Agnafors S, Sydsjö G: Self-reported mental health in 12-year-old second-generation immigrant children in Sweden. Nord J Psychiatry 2011, 65(6):389-395.

49. Comasco E, Sylvén SM, Papadopoulos FC, Oreland L, Sundström-Poromaa I, Skalkidou A: Postpartum depressive symptoms and the BDNF Val66Met functional polymorphism: effect of season of delivery. Arch Womens Ment Health 2011, 14(6):453-463.

50. Cox JL, Holden JM, Sagovsky R: Detection of postnatal depression. Development of the 10-item Edinburgh Postnatal Depression Scale. $\mathrm{Br} J$ Psychiatry 1987, 150:782-786.

51. Nordberg L, Rydelius PA, Nylander I, Aurelius G, Zetterström R: Psychomotor and mental development during infancy. Relation to psychosocial conditions and health. Part IV of a longitudinal study of children in a new Stockholm suburb. Acta Paediatr Scand Suppl 1989, 353:1-35.

52. Achenbach TM: Manual for the Child Behavior Checklist/4-18 and 1991 Profile. Burlington, VT: Department of Psychiatry, University of Vermont; 1991a.

53. Derogatis LR, Lipmann RS, Rickels K: The Hopkins symptoms checklist (HSCL): a self-report inventory. Behav Sci 1974, 19:1-15.

54. Greenwald R, Rubin A: Brief assessment of children's post-traumatic symptoms: Development and preliminary validation of parent and child scales. Res Soc Work Practice 1999, 9:61-75.

55. Larsson I: LITE-P, life incidence of traumatic events. (Translation into Swedish, with permission from the author Greenwald R.). Linköping: Linköping University; 2003.

56. Matthey S, Henshaw C, Elliot S, Barnett B: Variability in use of cut-off scores and formats on the Edinburgh Postnatal Depression Scale - implications for clinical and research practice. Arch Womens Ment Health 2006, 9:309-315.

57. Nettelbladt P, Hansson L, Stefansson CG, Borgquist L, Nordström G: Test characteristics of the Hopkins symptom check list-25 (HSCL-25) in Sweden, using the present state examination (PSE-9) as a caseness criterion. Soc Psychiatry Psychiatr Epidemiol 1993, 28(3):130-133.

58. Duncan LE, Keller MC: A critical review of the first 10 years of candidate gene-by-environment interaction research in psychiatry. Am J Psychiatry 2011, 168(10):1041-1049.

59. Thomson CC, Roberts K, Curran A, Ryan L, Wright RJ: Caretaker-child concordance for child's exposure to violence in a pre-adolescent inner-city population. Arch Pediatr Adolesc Med 2002, 156:818-823.

60. Angold A, Costello EJ, Erkanli A: Comorbidity. J Child Psychol Psychiatry 1999, 40(1):57-87.

61. Laucht $M$, Treutlein J, Blomeyer D, Buchmann AF, Schmid B, Becker $K$, Zimmermann US, Schmidt MH, Esser G, Rietschel M, Banaschewski T: Interaction between the 5-HTTLPR serotonin transporter polymorphism and environmental adversity for mood and anxiety psychopathology: evidence from a high-risk community sample of young adults. Int $J$ Neuropsychopharmacol 2009, 12(6):737-747.

62. van der Toorn SL, Huizink AC, Utens EM, Verhulst FC, Ormel J, Ferdinand RF: Maternal depressive symptoms, and not anxiety symptoms, are associated with positive mother-child reporting discrepancies of internalizing problems in children: a report on the TRAILS study. Eur Child Adolesc Psychiatry 2010, 19(4):379-388.

63. Feder A, Nestler EJ, Charney DS: Psychobiology and molecular genetics of resilience. Nat Rev Neurosci 2009, 10(6):446-457.

doi:10.1186/1753-2000-7-10

Cite this article as: Agnafors et al.: Effect of gene, environment and maternal depressive symptoms on pre-adolescence behavior problems - a longitudinal study. Child and Adolescent Psychiatry and Mental Health 2013 7:10. 